\title{
EVALUASI KESUBURAN TANAH DI DUSUN KEKAWII III DESA RANDOTONDA KECAMATAN ENDE KABUPATEN ENDE
}

\author{
Sebastianus Kuswara, Charly Mutiara \\ Program Studi Agroteknologi, Fakultas Pertanian-Universitas Flores \\ Jln. Sam Ratulangi, Kel. Paupire, Kab. Ende \\ Charlyinter1988@gmail.com
}

\begin{abstract}
ABSTRAK
Evaluation soil fertility in dusun kekawii III randotonda Village, Ende District, Ende Regency. This study aims to determine the physical properties of the soil and the level of suitability of the land in Kekawii III hamlet, Randotonda village, Ende District, Ende Regency. Research is exploratory research, by evaluating physical properties, the evaluation results are described and compared with the standard physical properties of existing soil. The results of the study show that the soil properties in Kekawii III Hamlet are the soil texture of the sandy soil, clay. In structures, the types that exist are rounded lumps, lumpy angles, granular structures. On the color of the land dominated by Dark brown, Very dark gray, Very dark grayish brown. The consistency of land, it can be seen that these lands have a consistency that is sticky, plastic, loose, soft. The $\mathrm{pH}$ of the soil ranges from 4.2-6.4 and the slope ranges from $5 \%-12 \%$
\end{abstract}

Keywords: Fertility, Soil Physical Properties.

\section{PENDAHULUAN}

Desa Randotonda merupakan salah satu Desa yang berada di Daerah Nuabosi.Daerah inimerupakan penyedia ubi kayu yang sangat terkenal kekhasan rasanya, yang dikenaldengan nama ubi Nuabosi.Berbagai komoditas pertanian yang dibudidayakan pada lahan pertanian di Desa Randotonda makin menurun hasilnya dari tahun ke tahun. Penurunan hasil pertanian ini sangat nampak pada komoditi khas daerah tersebut, yaitu ubi kayu Nuabosi.

Data yang ada menunjukan adanya penurunan produksi ubi kayu dari tahun ke tahun di Kabupaten Ende pada tahun 2015 dengan luas panen 2695 ha adalah sebesar 32,880 ton, sedangkan pada tahun 2016 dengan luas panen 2731 ha adalah 32,471 ton, selanjutnya pada tahun 2017 dengan luas panen 2822 ha adalah sebesar 29,891 ton (BPS Kabupaten Ende, 2017).

Penurunan hasil tanaman ubi kayu disebabkan oleh beberapa faktor diantaranya curah hujan. Data curah hujan di Kabupaten Ende pada tahun 2015 dengan rata-rata jumlah curah hujannya sebesar $619 \mathrm{~mm}$, pada tahun 2016 sebesar $1134 \mathrm{~mm}$ dan pada tahun 2017 dengan rata-rata curah hujan sebesar $1409 \mathrm{~mm}$ (BPS Kabupaten Ende, 2017). Hujan berkaitan dengan adanya kelembapan yang tinggi, hal itu mengakibatkan terjadinya serangan jamur dan bakteri pada batang, daun dan umbi apabila drainase kurang baik sehingga mempengaruhi hasil tanaman ubi kayu (Titik Sundari, 2010).

$$
\text { Faktor lain penyebabkan }
$$
menurunnya hasil tanaman ubi kayu ialah Pengolahan tanah. Pengolahan tanah yang 
kurang optimal dapat berdampak pada penurunan kesuburan tanah serta hasil tanaman. Sistem pengolahan tanah dapat dibagi menjadi tiga yaitu pengolahan tanah yang minimum yaitu pengolahan tanah yang dilakukan hanya seperlunya sajah sedangkan pengolahan tanah intensif yaitu suatu tindakan pengolahan tanah yang dilakukan di seluruh permukaan tanah sampai keadaan tanah gembur dan tanpa olah tanah. Pengolahan tanah secara intensif dapat membawa keuntungan pada proses awal tanam diantaranya bisah mendapatkan hasil panen yang tinggi dan juga membawa pengaruh yang buruk bagi struktur tanah yang akan menjadi rusak, erosi dan penurunan kandungan bahan organik serta terjadinya penurunan produktivitas (Arsyad, 1989).

Kemiringan lereng juga merupakan faktor yang dapat mempengaruhi penurun hasil ubi kayu. Hal ini sesuai dengan hasil penelitian yang telah dilakukan oleh (Saribun, 2007) yang menyatakan bahwa pada suatu lahan yang memiliki tingkat kemiringan lereng yang curam mengakibatkan terjadinya erosi yang besar, ditambah lagi keadaan tersebut akan membuat tanah menjadi gembur serta memperhalus agregat tanah. Terbentuknya agregat tanah yang halus akan menyebabkan bobot isi tanah menurun dan porositas tanah yang tinggi, bila hal tersebut terjadi secara terus menerus maka akan berdampak padamenurunnya kualitas tanah, kesuburan tanah serta berkurangnya lapisan atas tanah yang dapat menyebabkan kurangnya hasil tanaman.

Selain itu penerapan sistem pola tanam secara monokultur juga dapat membawah dampak yang kurang baik bagi pertumbuhan tanaman dikarenakan penerapan sistem tersebut hanya akan menyerap unsur hara tertentu sajah dan dalam jumlah yang banyak, sedangkan hara lain tidak diserap dalam jumlah yang sama dalam waktu yang lama, sehingga pola tanam menokultur dapat menyebabkan ketidak seimbangan penyerapan unsur hara dalam tanah. Pola tanam ubikayu tunggal dan pemupukan dimanfaatkan sebagai petunjuk awal untuk mengembangkan pengelolaan lahan guna meningkatkan pendapatan secara berkelanjutan untuk usahatani. Penerapan sistem pola tanam monokultur dapat menyebabkan defisiensi pada suatu jenis unsur hara karena kurangnya pengembalian residu tanaman ke dalam tanah. Selain itu juga berdampak buruk terhadap sifat fisika tanah karena pelemahan struktur tanah dan penurunan infiltrasi tanah (Ismail dkk,1978).

Permasalahan-permasalahan diatas dapat diselesaikan dengan adanya kriteria kesesuaian lahan dan data-data sifat fisik. Berdasarkan uraian di atas, maka akan dilakukan penelitian dengan judul'Evaluasi Kesuburan Tanah Pada Dusun Kekawii III Desa Randotonda Kecamatan Ende Kabupaten Ende".

\section{Tujuan Penelitian}

1. Mengetahui sifat fisik tanah pada lahan pertanian di Desa Randotonda.

2. Mengetahui tingkat kesesuaian lahan yang ada di Desa Randotonda.

\section{METODE PENELITIAN}

\section{Tempat dan Waktu Penelitian}

Penelitian dilakukan pada areal pertanian yang terdapat pada Dusun KekawiiIII, Desa Randotonda, Kecamatan Ende, Kabupaten Ende. Penelitian dilakukan mulai bulan Desember 2016 sampai April Tahun 2017.

\section{Bahan dan Alat Penelitian}


Bahan yang digunakan dalam penelitian ini adalah tanah sebagai media penelitian sedangkan peralatan yang digunakan yaitu abney level, pH meter, cangkul, parang, buku munsel, alat tulis, kamera, patok, kantong plastik.

\section{Rancangan Penelitian \\ Penentuan Titik Sampel}

Titik sampel sebanyak 50 titik yang berada di 5 (lima) lereng. Penentuan titik sampel diambil berdasarkan kemiringan lereng yaitu dari lereng yang paling rendah menuju ke lereng yang paling terjal. Setiap satu hamparan dibagi kedalam beberapa ulangan untuk pengambilan titik sampel. Titik sampel yang diambil sebanyak 50 titik sampel tanah yang berada dalam 5 lereng dengan jarak antara lereng bervariasi antara 30 meter sampai dengan 50 meter.

\section{Teknik Pengambilan Sampel}

Setiap titik sampel yang sudah ditentukan dilakukan pengamatan sifat fisik.Setiap titik yang sudah ditentukan digali tanahnya dengan kedalaman \pm 20 cmuntuk memperoleh lapisan tanah horison $\mathrm{O}$ (susunan bahan organik) kemudian tanah itu diambil sebanyak 500 gr yang dimasukan kedalam kantong plastik dan diberi kode.

\section{Variabel Pengamatan}

Variabel yang diamati dalam penelitian ini adalah tekstur tanah, struktur tanah, konsistensi tanah, warna tanah, kemiringan lereng dan ph tanah.

\section{Analisis Data}

Sampel tanah yang diambil dianalisis secara kualitatif untuk mendapatkan data sifat fisik tanah. Data sifat fisik tanah yang telah didapat dianalisis kriteria kesesuaiannya dengan tabel kesesuaian lalu ditentukan kelas kesesuaian lahannya menggunakan Kriteria kelas kesesuaian lahan dari PPT (1950).

\section{HASIL DAN PEMBAHASAN}

Hasil

Sifat fisik tanah pada lahan-lahan yang terdapat di Desa Randotonda yang diamati yaitu tekstur, struktur, konsistensi, warna tanah, $\mathrm{pH}$ tanah dan kemiringan lereng. (Taberl.1)

Tabel 1 Hasil Analisis Sifat Fisik Tanah

\begin{tabular}{lll}
\hline \multicolumn{1}{c}{ Sifat Fisik Tanah } & \multicolumn{1}{c}{ Karakteristik } \\
\hline Tekstur & & $\begin{array}{l}\text { Liat berpasir, Lempung berliat } \\
\text { Gumpal membulat, Gumpal bersudut, } \\
\text { Granuler } \\
\text { Lekat, Agak lekat, plastis, Gembur, Lunak }\end{array}$ \\
Konsistensi & & $\begin{array}{l}\text { Dark brown, Very dark gray, Very dark } \\
\text { grayish brown } \\
\text { Warna Tanah }\end{array}$ \\
pH Tanah & $\begin{array}{l}4,2-6,4 \\
5 \%-12 \%\end{array}$ \\
Kemiringan Lereng & $\begin{array}{l}\text { menyediakan hara tinggi. Struktur tanah } \\
\text { berada pada horison A yang mana }\end{array}$ \\
tersebut menunjukan karakteristik dan \\
kesuburan dari lahan yang ada di \\
$\begin{array}{l}\text { Randotonda yang bertekstur tanah } \\
\text { lempung berliat dan liat berpasir yang } \\
\text { mana kemampuan menahan air dan }\end{array}$
\end{tabular}


klasifikasi landai lahan yang cocok untuk usaha tani. Dengan $\mathrm{pH}$ tanah 4,2 sampai 6,4 didominasi dengan $\mathrm{pH}$ tanah sekitar netral karena pada $\mathrm{pH}$ tanah tersebut kebanyakan unsur hara mudah larut dalam air sehingga memudahkan tanaman untuk menyerap unsur hara.Analisis sifat tanah ini diambil dari 50 titik sampel yang ada di dusun tersebut. Hasil analisis disajikan pada Tabel 1 di bawah ini.

\section{PEMBAHASAN}

\section{Tekstur Tanah}

Tekstur tanah berhubungan dengan kasar atau halusnya tanah sehingga adanya perbedaan antara pasir dan liat pada tanah yang mampu menyediakan unsur-unsur yang esensial (Foth, 1991).Berdasarkan hasil pengamatan tekstur tanah dilapangan jika disesuaikan dengan kriteria kesesuaian lahan untuk tanaman ubi kayu termasuk alam kategori cukup sesuai, yaitu lahan dengan faktor-faktor pembatas yang apabila bekerjasama akan menghambat dukungan pertumbuhan tanaman tertentu. Penghambat tersebut akan mengurangi produktivitas atau keuntungan dan meningkatkan masukan yang diperlukan sehingga ada keuntungan keseluruhan yang diperoleh dari penggunaan tersebut. Sedangkan untuk tanaman kakao dan cengkeh berada pada kategori sangat sesuai dikarenakan lahan yang sangat sesuai tidak memiliki faktor pembatas nyata apabila digunakan, atau hanya sedikit pembatas yang tidak secara nyata mengurangi produktivitas dan keuntungan serta tidak meningkatkan masukan melebihi aras taraf yang dapat diterima

Hasil analisis tekstur tanah yang telah dilakukan di Desa Randotonda menunjukan bahwa tekstur tanah di daerah tersebut terdiri dari lempung berliat dan liat berpasir. Tipe tekstur ini termasuk dalam kategori tekstur halus hingga sedangsehingga memiliki kemampuan menahan air yang baik serta aktif dalam reaksi kimia dibandingkan dengan tanah bertekstur kasar(Hardjowigeno, 2002).

\section{Struktur Tanah}

Struktur tanah yang ditelah dianalisis dari Desa Randotonda adalah gumpal membulat, gumpal bersudut dan granular. Struktur dengan sudut yang tajam dikatakan gumpal bersudut dan jika sudutnya membulat maka dikatakan gumpal membulat sedangkan struktur dengan agregat yang membulat dikatakan granular. Kedua struktur diatas memiliki ukuran yang mencapai $10 \mathrm{~cm}$ dibandingkan dengan struktur granular yang hanya memiliki ukuran tidak lebih dari $2 \mathrm{~cm}$ (Hanafiah, 2010).

\section{Konsistensi Tanah}

Konsistensi tanah merupakan kemampuan tanah dalam menghadapi perubahan bentuk berdasarkan sifat kohesi dan adhesi (Nugroho, 2009). Tanah dikatakan lunak ketika dalam keadaan basah, saat kering tanah lunak memiliki konsistensi yang gembur. Tanah lengket ketika air tanah terhubung keseluruh tanah, sedangkan tanah cair ketika kelembapan suatu tanah yang mendekati tingkat kejenuhan sifat tanah (Lal, Shukla,2004).

Dalam konsistensi terdapat berbagai tingkat kelembapan diantaranya basah, lembab dan kering. Pada tanah tertentu tanah tersebut akan menjadi lekat ketika tanah dalam keadaan basah, teguh ketika tanah dalam keadaan lembab dan jika dalam keadaan yang kering tanah tersebut akan menjadi keras. Pengukuran konsistensi tanah pada saat kering yaitu berdasarkan tingkat kekerasannya, yakni tanah yang lepas, lunak, agak keras, keras, 
sangat keras atau keras sekali. Tingkat Kekerasan tersebutmemiliki hubungan yang erat terhadap kandungan liat tanah sedangkan pada tanah yang lembab, konsistensi tanah diukur berdasarkan tingkat kepadatannya, yaitu tanah yang lepas, sangat remah, remah, padat, sangat padat atau padat sekali(Radjit dkk,2014).Tanah dengan konsistensi gembur cocok untuk tanaman ubi kayu dikarenakan mempunyai tata udara yang baik serta unsur hara lebih cepat tersedia dan mudah untuk diolah (Bargumono, 2012).

\section{Warna Tanah}

Warna tanah termasuk dalam sifat tanah yang mudah ditentukan, warna tanah juga memiliki fungsi yang kecil terhadap kegunaan tanah walaupun demikian warna tanah juga mampuuntuk menjelaskan adanya sifat yang khusus dari suatu tanah. Cara dalam menentuan warna tanah yaitu dengan membandingkan warna tanah warna yang terdapat dalam buku Munsell Soil Color Chart. Gambaran warna inti disusun atas tiga variabel diantaranyahue, value dan chroma, hue adalah warna spektrum yang dominan sesuai dengan panjang

gelombangnya.Valuememperlihatkan gelap atau terangnya suatu warna , berdasarkan jumlah sinar yang dipantulkan dan Chromamenampilkan kekuatan yang ada pada warna spektrum. Chroma juga diartikan sebagai gradasi kemurnian dari warna atau derajat pembeda adanya perubahan warna dari kelabu atau putih netral ke warna lainnya (Gusli, 2015). Warna tanah dari sampel-sampel tanah yang diambil di Randotonda adalah Dark brown, Very dark gray, Very dark grayish brown atau berwarna gelap.
Makin gelapnya suatu tanah berarti makin meningkat produktivitasnya. Penentuan warna tanah berdasarkan tingkat kesuburannya dari yang terendah diantaranya putih, kuning, kelabu, merah, coklat-kekelabuan, coklat-kemerahan, coklat, dan hitam. Kondisi adalah integrasi dari pengaruh kandungan bahan organik yang berwarna gelap. Tanah yang memiliki kandungan bahan organik makin tinggi maka tanah tersebut akan berwarna makin gelap (Harjowigeno, 2010). Dengan begitu, maka dapat diketahui bahwa tanahtanah yang ada di Desa Randotonda mempunyai kandungan bahan organik yang tinggi.

Selain bahan organik, intensitas pelindihan juga sangat mempengaruhi dalam perubahan warna tanah. Intensitas pelindian merupakan pencucian unsurunsur dari horison bagian atas ke horison bagian bawah dalam tanah. Makin kuat proses pelindihan mengakibatkan warna tanah akan lebih terang, seperti pada horison eluviasi, dan Kandungan kuarsa yang tinggimengakibatkan tanah berwarna lebih terang (Hanafiah, 2014). Hal ini menunjukan bahwa tanah-tanah yang ada di Desa Randotonda tidak mengalami pencucian yang intensif.

\section{Kemiringan lereng}

Kemiringan lereng adalahsuatu ukuran kemiringan lahan yang tidak mutlak terhadap bidang datar yang sering dinyatakan dalam persen atau derajat. curamnya lereng, panjang lereng serta bentuk lereng akan mempengaruhi besarnya erosi dan aliran permukaan (Sitanala, Arsyad, 1989).

Hasil pengukuran kemiringan lereng yang ada di desa Randotonda menunjukan bahwa lahan-lahan yang ada di Desa tersebut berada pada kondisi sangat landai 
sampai landai. Hal ini terlihat dari nilai kemiringan lereng yang berada pada $5 \%$ $12 \%$. Nilai ini menjelaskan bahwa proses erosi disekitar daerah penelitian terjadi dalam jumlah kecil. Erosi merupakan proses pengikisan tanah oleh air, erosi juga berhubungan dengan kemiringan lereng. Semakin curamnya lereng menyebabkan jumlah serta semakin cepatnya aliran air diatas permukaan tanah sehingga memperbesar energi kinetik dan meningkatkan kemampuan untuk mengangkut tanah (Sidik, Fajar, 2010).

Hasil dari pengukuran diatas bila disesuaikan dengan kriteria kesesuaian lahan untuk tanaman ubi kayu, cengkeh dan kakaoberada pada kategoricukup sesuai dikarenakan lahan dengan faktorfaktor pembatas yang apabila bekerjasama akan menghambat dukungan pertumbuhan tanaman tertentu. Penghambat tersebut akan mengurangi produktivitas atau keuntungan dan meningkatkan masukan yang diperlukan sehingga ada keuntungan keseluruhan yang diperoleh dari penggunaan tersebut.

\section{pH Tanah}

Derajat keasaman tanah atau $\mathrm{pH}$ (potential of hidrogen) tanah termasuk faktor yang mempengaruhi kelarutan unsur hara dalam tanah. Menurut (Soemarno, 2013), tersedianya unsur hara makro dan mikro dalam tanah dipengaruhi oleh $\mathrm{pH}$ tanah. Pada tanah agak masam sampai agak alkalis, ketersediaan unsur makro dan Mo meningkat (kecuali P), sedangkan hara $\mathrm{P}, \mathrm{Fe}, \mathrm{Mn}, \mathrm{Zn} \mathrm{Cu}$, and $\mathrm{Co}$ menjadi tidak tersedia sehingga dapat mempengaruhi pertumbuhan tanaman. Pada tanah masam, hara mikro (kecuali Mo and Bo) terjadi penurunan. (Soomro dkk, 2012) menjelaskan bahwa tanah dengan nilai $\mathrm{pH}$ yang tinggi akan menyebabkan terjadinya masalah fiksasi $\mathrm{P}$ dan berdampak pada kurangnya ketersediaan hara bagi tanaman.

Reaksi tanah mempengaruhi proses kimia dalam tanah, diantaranya bahan organik serta pembentukan mineral lempung yang dipengaruhi oleh $\mathrm{pH}$ tanah. secara tidak lansung Pertumbuhan tanaman dipengaruhi oleh reaksi tanah. Pengaruh tidak lansung terhadap tanah melalui tersedianya hara bagi tanaman. Perubahan $\mathrm{pH}$ tanah juga akan menyebabkan perubahan konsentrasi fosfat tersedia dalam tanah bagi tanaman (Tan, 1998).

$\mathrm{pH}$ tanah yang berada antara 4,6 6,4 bila dicocokan dengan kriteria kesesuaian lahan untuk tanaman ubi kayu, cengkeh dan kakao berada pada kategori kurang sesuai, dikarenakan adanya faktorfaktor pembatas yang apabila bekerjasama akan sangat menghambat dukungan terhadap pertumbuhan tanaman tertentu. Penghambat tersebut sangat memengaruhi produktivitas atau keuntungan dan meningkatkan masukan yang diperlukan sehingga keuntungan keseluruhan yang diperoleh dari penggunaan sangat rendah, bahkan tidak untung. Pemakaian lahan kelas ini dipertimbangkan marginal (membutuhkan input besar untuk memperoleh hasil cukup sehingga keuntungan terbatas).

\section{SIMPULAN}

Berdasarkan data sifat fisik tanah yang telah diamati dan jika disesuaiakan dengan tingkat kesesuaian lahan maka disimpulkan bahwa tanaman yang cocok untuk ditanam pada lahan pertanian di Dusun Kekawii III Desa Randotonda adalah tanaman ubi kayu.

\section{UCAPAN TERIMA KASIH}

Pada kesempatan ini penulis ingin mengucapkan terima kasih kepada semua pihak yang telah membantu dengan 
caranya masing-masing dalam melengkapi tulisan ini

\section{DAFTAR PUSTAKA}

Arsyad, S. 2000. Konservasi Tanah dan Air. Institut Pertanian Bogor Press. Bogor.

Arsyad, S. 1989. Konservasi Tanah dan Air. Penerbit IPB Press. Bogor.

Badan Pusat Statistik Kabupaten Ende. 2017. Ende Dalam Angka. Badan Pusat Statistik Kabupaten Ende.

Gusli, S. 2015. Penuntun Praktikum Dasar-dasar Ilmu tanah. Makassar: Fakultas Pertanian Universitas Hasanuddin Makassar.

Hadi Utomo,W. 1992. Dasar-dasar Fisika Tanah. Jurusan Tanah FakultasPertanian Universitas Brawijaya : Malang

Hakim,N; Nyakpa, M. Y.; Lubis, A.M.; Nugroho, s.G. ; sail ,M.R.; Diha, M.H. ; Hong, G.B. danBailey, H.H., 1986. Dasardasarilmu tanah. Penerbit universitas Lampung.

Hanafiah, K.A. 2010. Dasar-dasar Ilmu Tanah. Jakarta: Rajawali Pers.

Hardjowigeno 2010 ://E:/Sifat Fisika Tanah bagian 5 Konsistensi . html akses Mei 2014.

Hardjowigeno, H. Sarwono. 2002. Ilmu Tanah. Mediyatama Sarana Perkasa: Jakarta.

Hardjowigeno, S. 1993. Klasifikasi Tanah dan Pedogenesis.

Akademika Pressindo Jakarta.

Kartasapoetra, A. Gunarsih. 1986. Klimatologi: Pengaruh Iklim TerhadapTanah dan Tanaman. Bumi Aksara. Jakarta.

Kurnia, U.F., Agus., A. Adimihardja Manfarizah, Syamaun, S. Nurhaliza. 2011. Karakteristik Sifat
Fisika Tanah diUniversity Farm Stasiun Bener Meriah Agrista.vol 15 (1).., A. Dairah., 2006. Sifat Fisik Tanah dan Metode Analisisnya. Badan Penelitian dan Pengembangan Pertanian, Departemen Pertanian.

Lal, R., Shukla, MK 2004. Prinsip Fisika Tanah. Marcel Dekker Inc., New York

Manfarizah, Syamaun, S. Nurhaliza. 2011. Karakteristik Sifat Fisika Tanah diUniversity Farm Stasiun Bener Meriah Agrista, vol 15 (1).

Naldo, R.A., 2011. Sifat Fisika Ultisol Limau ManisTiga Tahun Setelah Pemberian Beberapa Jenis Pupuk Hijaun. J. agroland. Fakultas Pertanian. Universitas Andalas.

Nugroho, Y. 2009..Analisis Sifat Fisik Kimia dan Kesuburan Tanah pada Lokasi

Rencana Hutan Tanaman Industri PT Prima Multibuana. J HutanTropis.

Nurhidayati, 2006. Penuntun Praktikum Dasar-Dasar Ilmu Tanah. Fakultas Pertanian Unisma Malang.

Radjit, B.S., Y. Widodo., N. Saleh., dan N. Prasetiaswati. 2014. Teknologi Untuk Meningkatkan Produktivitas dan Keuntungan Usaha tani Ubi kayu di Lahan Kering Ultisol. J. IPTEK Tanaman Pangan.

Rosyidah.E, Wirosoedarmo. R., 2013. Pengaruh Sifat Fisik Tanah pada Konduktivitas Hidrolik Jenuh Di 5 Penggunaan Lahan (Studi Kasus Di Kelurahan Sumber sari Malang). J. AGRITECH. Fakultas Teknologi Pertanian, Universitas Brawijaya. 
Saleh, (2010) Perbaikan struktur tanah pada lahan sangat curam dengan menggunakan teknik hidrosiding lumut daun dan bahan pembenah tanah. JIPI 12 (1). pp. 1-6.

Salim, E.H. 1998. Pengelolaan Tanah. Karya Tulis. Jurusan Ilmu Tanah Fakultas Pertanian Universitas Padjadjaran. Bandung.

Saribun, D. (2007) : Pengaruh Jenis Penggunaan Lahan dan Kelas Kemiringan Lereng Terhadap Bobot Isi, Porositas Total, dan Kadar Air Tanah Pada Sub-DAS Cikapundung Hulu, Jurusan Ilmu Tanah, Fakultas Pertanian, Universitas Padjajaran, Jatinangor.

Sidik, Fajar. 2010. Analisis Stabilitas Lereng Untuk Zonasi Daerah Rawan Longsor di DAS Secang Kulonprogo Dengan Menggunakan Model Deterministik. Skripsi. Fakultas Geogorafi-Universitas Gajah Mada. Yogyakarta.

Sitanala, Arsyad. 1989. Konservasi Tanah dan Air. Bogor: Penerbit IPB Press.

Soemarno. 2013. Bahan Ajar Matakuliah Dasar Ilmu Tanah: Reaksi Tanah (pH). www.marno. lecture.ub.ac.id. diunduh Tgl.10 Desember 2013.

Sutanto, Rachman. 2005. Dasar-Dasar Ilmu Tanah Konsep dan Kenyataan. Yogyakarta: Kanisius

Tan H. K 1998. Dasar-Dasar Kimia Tanah. Gajah Mada Universitas Press Yogyakarta, Indonesia

Titik, Sundari. 2010. Pengenalan Varietas Unggul dan Teknik Budidaya Ubi Kayu. Report No. 55. STE. Final.

Yunus, Yuswar. 2006. Tanah dan Pengolahan. CV Alfabeta. Bandung. 